\title{
Gabriel Garcia Marquez; The Significant Message of His Literary Discourse
}

\author{
Mohammad B. Aghaei \\ Department of English language, Islamic Azad University, Tabriz Branch, Tabriz, Iran \\ E-mail: aghaeimb@yahoo.com
}

Received: 22-08-2014

Accepted: $30-10-2014$

Published: 01-03-2015

doi:10.7575/aiac.ijalel.v.4n.2p.185

URL: http://dx.doi.org/10.7575/aiac.ijalel.v.4n.2p.185

\begin{abstract}
Gabriel Garcia Marquez's literary discourse actually portrays the destructive domination of colonial and imperialistic powers and civil wars that led to a series of insecurities and poverty in the community. In fact, whatever he has presented in his works is related to the realities of the continent that have been portrayed in his fictional world. In his works, every single line is a reference to a certain critical point in the history of Latin American continent and provides a magnifying glass for the reader to clearly conceptualize them. His works also represent the contemporary events that are frequently happening in the society.
\end{abstract}

Keywords: Latin America, figurative techniques, legacy of colonialism, violence, Liberal and Conservative parties

\section{Introduction}

Gabriel Garcia Marquez, born on 6th March 1928 in Aracataca, a small town in Northern Colombia, is one of the bestknown writer of our time who has emerged from the Third World. He is the most widely admired novelist in Latin America, even in Europe and the United States due to his expertise and mastery on the unique way of applying various literary techniques and styles. Over the last four decades, his literary reputation has reached to the point that he has been considered at the level of the great writers such as Dickens, Hugo and Hemingway. In 1982, he was the most qualified figure who won the Nobel Prize for Literature. He is not only a rare phenomenon in literature but also one of the four or five biggest personalities of the twentieth century in Latin America.

Marquez achieves a universal success by publishing his masterpiece, One Hundred Years of Solitude. This masterpiece appeared on the cusp of the transition between modernist and postmodernist fiction, and may be only novel between 1950 and 2009 that has found large number of enthusiastic readers. It is probably not an exaggeration to claim that it is the world's first truly global novel. Like those of Shakespear, the titles of his books "appear in ghostly fashion in the headlines of newspapers all over the planet ('one hundred hours of solitude,' 'chronicle of a catastrophe foretold', 'autumn of the dictator', 'love in the time of money')....His favours and his friendship have been sought by rich, the famous and the powerful-Francois Mitterrand, Felipe Gonzalez, Bill Clinton, most of the recent presidents of Colombia and Mexico, and many other celebrities besides" (Martin 2008: xx).

He has grown up in a town of less that ten thousand mainly illiterate inhabitants, with unpaved streets, no drainage and a name, Aracataca, which makes people laugh when they first hear it. Very few famous writers from any part of the world have come from such a small-town background, and yet fewer have lived their era, both culturally and politically, as fully and intimately as him. According to Martin (2008), during his literary career, Marquez has produced many literary works ${ }^{1}$ that have been translated into more than thirty well-known languages and published with more than twenty million copies till now.

\section{His Literary Oeuvre}

Although Marquez's masterpiece One Hundred Years of Solitude is only enough to place him in the ranks of twentieth century top writers, his reputation is also related to his other works that have been recognized by critics and readers as outstanding works in literature. His works have actually made the Latin American literature comparable with the Russian literature of the 19th century because their central themes are similar such as truth, illusion and solitude.

Marquez's works are fertilized with multiple layers of meanings particularly by adroitly applying figurative techniques and his special craft of writing. In his literary discourse, "both realistic and fantastic or supernatural events are narrated exactly the same, thus making the reader believe that they are both truthful representations of what is occurring in the story. This is an important aspect of his writing because it allows for a kind of political, cultural, and even religious leniency in reflecting the cultural aspects" (Smith 2008). He is not content to look at issues just from the surface, but rather to boil every story down to its most vital essence. So, his works always offer significant messages to the reader about the realities of his country and Latin America.

Despite his former profession as a journalist, he has in fact rarely represented the realities in a straightforward way; he has always blurred the boundaries in his fictions such as boundary between fantasy and real, and between the past, the 
present and the future. He has chosen the 'magical realism' as an effective tool to depict those historical and cultural events that can not be easily represented by other literary techniques. On the other hand, he has taken off the seam between 'cold' reality and 'magic' for demonstrating the cultural complexity of Latin America. In his interview with Claudia Dryfus in Playboy, Marquez says that:

"Clearly, the Latin American environment is marvelous. Particularly the Caribbean. I happen to come from the Caribbean part of Colombia, which is a fantastic place - completely different from the Andean part, the highlands. During the colonial period of Colombian history, all the people who considered themselves respectable went to interior - to Bogota. On the coast, all that were left were bandits - bandits in good sense - and dancers, adventurers, people full of gaiety. The coastal people were descendants of pirates and smugglers, with a mixture of black slaves. To grow up in such an environment is to have fantastic resources for poetry. Also, in the Caribbean, we are capable of believing anything, because we have the influences of all those different cultures, mixed with Catholicism and our own local beliefs. I think that gives us an open-mindedness to look behind apparent reality. As a child growing up in the Caribbean village of Aracataca, I heard wonderful stories of people who were able to move chairs by simple looking at them. There was a man in Aracataca who had the facility for deworming cows-for healing their inflections - by standing in front of the beasts. He would stand in front of the cow and worms would start coming out of the head of the cow" (Dryfus 1983b: 112).

There is a crucial difference between the culture of Caribbean zone and the culture of high-Andean interior of Bogota. The culture of Caribbean zone is a conglomeration of African, Indian and Spanish cultures. In this zone, the influence of Spanish culture was strong due to the colonization by Spain in the sixteenth century. Marquez has mostly focused on the Caribbean zone where he was born. He has often depicted in his novels the characteristics of Afro-American culture which is a shared inheritance of the Caribbean people. His works present various cultural and historical mythologies in which the reality, imagination and magic are blended together in such a way that they contribute significantly to the aesthetic value of his works.

\section{His Literary Ideology}

Marquez is always keen on presenting to the people the various facets of their history. His literary language acts as effective means for describing the critical historical aspects of Latin America because the legacy of colonialism had destroyed so many important traces of the native culture of that area. This has led him to search for his identity by looking at various periods, before and after colonization. Because of this, the historical and cultural issues were his main thematic subject matters; such as savagely fought wars of independence, bloody conflict between the political parties, massacre of banana workers, deplorable effects of Hispanic culture on the community, imperialistic presence of foreign companies, disappearance of native traditional life and its replacement with modern life and eventually its devastating effect on the society. History, for the Latin Americans, has always meant memories of fire, of the great dictators, supported by the great powers, and of hundreds of years of solitude. Therefore, most of his works give an overall perspective on particular historical and political realities of Colombia since its independence from Spain in the early nineteenth century.

Marquez mostly stresses upon the historical cognition in order to affirm the idea that a consciousness of history is a necessary precondition for a society's survival and autonomous development. Because of this, the novel One Hundred Years of Solitude has a historical basis covering the history of his country and, in general, the Latin American continent. In this novel, the characters have lost the real meaning of life and made themselves busy with their own wrong behaviours. In fact, they don't take a reasonable mind for performing their daily activities. They believe that this is the way of life that should be. But they do not know that this world that they create for themselves will lead them to their destruction. If there is even a slight development, it always puts them in a devastating condition because of ignoring their own roots and identity. However, what is important to recognize is that Marquez has given the reader a deceptively cyclic history that moves the town towards its final annihilation. In fact, the narrative actually depicts the history such a way that it never leads them to a hopeful future; the future never seems to arrive and if it arrives it will become too late because the concept of time for them is circular, not in a linear progression or movement.

In 1940s, a series of violence occurred in Colombia. It was an almost twenty-year period of rural violence in which "over 200,000 people died at the hands of Liberal and Conservative guerilla bands, vigilantes, local authorities, and the army, and it was brought into full force by bogotazo " (Janes 1981: 13). This endless cycle of violence has been one of the central themes in some of his important works, especially the conflicts of the two parties and the massacre of banana workers were the main themes of One Hundred Years of Solitude and No One Writes to the Colonel. These books are set during the Violencia and the connection between the violence of 1940s and the civil wars of 1899-1902 that is known as 'War of a Thousand Days' that was largest internal war of the western hemisphere in the twentieth century. Bloody struggle between the two parties particularly emerged after independence of Colombia from Spain. These parties extended and continued their political struggles up to a point that puts Colombia at the highest level of political conflict in the world during the period of 1899-1948, the period that was full of extremely violent civil strife for capturing the state power.

In his novels, he mainly depicts the origins of violence, and their effects on the society in which people had to live. Of all these predicaments, perhaps the drug traffic was one of the most serious factors in the incidence of violence in Colombia's society. Particularly, it took a more serious form when drug traffickers who financially supported the paramilitary death squads, and on the other hand, they themselves also enjoyed apparently some degree of authorities' 
support. They kidnapped wealthy people, officials and well-known persons in order to gain more funds for their operations against the government and innocent people. Violence continued to be as the most distinguishing feature of Colombian society in 1970 s and 80 s.

Other types of violence also figure as main themes in his novels like the sexual harassment in Chronicle of a Death Foretold, and the oppressive behaviours of Catholic authorities in Of Love and Other Demons. Both as a journalist and a creative writer, he has tried to inform people in detail about the events that previously or recently happened in his country such as the capsizing of Colombian Navy Destroyer and kidnapping in The Story a Shipwrecked Sailor and News of a Kidnapping.

Marquez had also played an important role in the political affairs of the region. Several times, he had been supposed that he was able to help bring about an improvement in relations between the United States and Cuba. In many critical conditions of Colombia, he had acted as an intermediary between leftist party and government and he had been threatened to death from the members of right-wing paramilitary organization who did not want to negotiate with their enemies. He has also acted as a mediator between the families of abductees and kidnappers in the kidnapping of 1990. His novels were not only means for him to engage himself in the political affairs; he frequently took a more personal role for cultivating friendships with leading political figures such as Castro, Torrijos and Mitterrand.

Although Marquez did not show any inclination to join any rigid political party, he has the conviction like that of a socialist. He has never followed any rigid ideology. He believes in socialist revolution as the best course of development for Latin America. He always criticizes the imposition of any foreign ruling system on the region of Latin America. He even believes that the western democracy and communism are not suitable models for the region because the region has its own unique features that make it completely different from other cultures or societies. For this reason, he has always given a socio-political orientation to his literary discourse in order to highlight the salient features of his country. In fact, his artistic goal is to portray a comprehensive image of the past, present and future of Latin America in a symbolically contextualized fictional discourse.

\section{His Significant Message}

Marquez's literary discourse offers a multifaceted perspective on the Latin American continent, particularly Colombia and the Caribbean coast. In his novels, he does not merely chronicle the surreal, poignant plights of the Latin Americans but offers a mesmerizing portrayal of human conflict and folly. In fact, he dexterously relates the past realities to the present conditions of Latin America and then to the problems that one will probably face in the future. He wants to inform the reader about the root of all predicaments of this continent. At the same time, he offers effective suggestions and solutions for eliminating these problems and improving the present condition. However, by blurring the borders between the past, the present and the future, he portrays a new image of Latin America that is different from the one that has been depicted by other writers of the continent. At the end of the reading, the reader makes a connection with not only his past but also his traditions, conventions, culture and myths; the reader becomes aware of his identity and the identity of other groups and communities. In fact, his literary discourse attempts to restore the Latin American identity by making Latin Americans aware of their own culture, society and history.

For this reason, most of his novels have the political orientation in order to inform the reader about the events that have occurred in this continent. Because of the political slant of his novels, he always blends together the cultural aspects and the historical phenomena. By this way, he clearly represents the destructive effect of the domination of colonial powers in the past and of imperialistic powers in the present, on the economy and culture of the continent. In reality, that caused people to get themselves alienated from their own culture, the continent to be divided into different countries, the political parties to be formed and engaged themselves in bloody civil wars, the violence to cover almost all parts of the country and eventually hundreds of thousands of people to be killed. As a result, the continent became one of the most violent areas in the world at the beginning of twentieth century. These are main themes that constitute his literary discourse. Hence, his literary discourse always conveys highly significant messages that subtly suggest a special reverence for his social conventions and cultural values.

The period in which Marquez began to write was an important phase in the Latin American Literature. He indeed got recognition as a prolific writer in the 1950s; that was a period in which literature of the continent had taken a realistmodernist approach for portraying the region in a multi-faceted image. The realist-modernist trend started from the year of the bourgeois-democratic revolution in the continent, providing the Latin American writers with a new literary direction to depict the violent realities of the continent in their works. The perception and depiction of these realities were the main concerns of these writers during this period. Being part of this milieu, Marquez aimed at offering a wonderfully sharp and sardonic description of the social peculiarities and the tragic history of the region in his fictional works, which were quite dense in implication and exalting in their sadness.

No doubt, Marquez is a story-teller of the first order in any idiom. His masterpiece One Hundred Years of Solitude is a remarkable breakthrough in the literary world of fiction which has been recently selected as one of the best books of the second half of the twentieth century. It is an outstanding work of fiction that sets in motion a complex chain of events which compels the reader to cross and recross the divide between the real and imaginary. Because of its style of narration, this novel has been compared with Cervantes's Don Quixote. Gerald Martin (Marquez's official biographer) would like to call Gabo (Marquez's nick name) the new Cervantes.

During the five decades of his writing career, Marquez has produced an astounding variety of works that has got him the status of an author who is convincingly one of the best to be found anywhere. He is the first Colombian and the 
fourth Latin American who has won the Nobel Prize for Literature in 1982. Any lover of fiction reading his books is unlikely to forget them.

\section{References}

Bell-Villada, Gene H. (1983). "Building a Compass." In: Bell-Villada, Gene H. (2006). Conversations with Gabriel Garcia Marquez. Jackson, US: University Press of Mississippi. pp. 133-140.

Bell-Villada, Gene H. (2009). Garcia Marquez: The Man and His Work. Second Edition. Chapel Hill: University of North Carolina Press.

Dryfus, Claudia (1983). "Playboy Interview: Gabriel Garcia Marquez.” Playboy, February, volume 3, pp. 65-77.

Dryfus, Claudia (1983b). "Playboy Interview: Gabriel Garcia Marquez." In: Bell-Villada, Gene H. (2006). Conversations with Gabriel Garcia Marquez. Jackson US: University Press of Mississippi. pp. 96-132.

Gullon, Ricardo (1971). "Gabriel Garcia Marquez and the Lost Art of Storytelling.” In: McMurray, George (1987). Critical Essays on Gabriel Garcia Marquez. Boston: G.K. Hall and Co. pp.129-139.

Hamill, Pete (1988). "Love and Solitude." (Interview with Gabriel Garcia Marquez). Vanity Fair, March, pp. 124-131.

Janes, Regina (1981). Gabriel Garcia Marquez: Revolutions in Wonderland. Missouri, Colombia: University of Missouri Press.

Marquez, Gabriel G. (1981). “The Art of Fiction.” (The Paris Review Interviews II). In: Gourevitch, Phillip (2007). Gabriel Garcia Marquez: The Art of Fiction. New York: Picador. pp. 178-206.

Martin, Gerald (2008). Gabriel Garcia Marquez: A Life. London: Bloomsbury Publishing Plc.

McMurray, George R. (1977). Gabriel Garcia Marquez. New York: Frederick Ungar Publishing Co.

Minta, Stephen (1987). Gabriel Garcia Marquez: Writer of Colombia. London: Jonathan Cape.

Pelayo, Ruben (2001). Gabriel Garcia Marquez: A Critical Companion. Westport: Greenwood Press.

Rodriguez-Vergara, Isabel (1998a). "Introduction: Critical Essays on the Work of Garcia Marquez." Trans. Anna Serra. Washington, DC: Organization of American States, no. 64, pp.2-6.

(1998b). "Sacred Parody in Love in the Time of Cholera: Critical Essays on the Work of Garcia Marquez." Trans. Anna Serra. Washington, DC: Organization of American States, no. 64, pp. 35-43.

(1998c). "The General in his Labyrinth: Writing as Exorcism: Critical Essays on the Work of Garcia Marquez."

Trans. Anna Serra. Washington, DC: Organization of American States, no. 64, pp. 45-59.

(1998d). "Of Love and Other Demons: Burning the Colonial Devil: Critical Essays on the Work of Garcia Marquez.” Trans. Anna Serra. Washington, DC: Organization of American States, no. 64, pp. 73-82.

Samper, Maria E. (1989). “An Interview with Gabriel Garcia Marquez.” Semana, volume 14, pp. 27-33.

Simons, Marlise (1982). "A Talk with Gabriel Garcia Marquez.” New York Times, December 5, Late City Final Edition, Section 7, Page 7, Column 1.

\section{Internet Source}

Smith, Nicole (2008). "Gabriel Garcia Marquez: Politics, Society, and Fiction in Context." Myriad. http://www.articlemyriad.com/107.htm

\section{Notes}

${ }^{1}$ The following works of fiction have all appeared in English translation. They are listed in order of their original, Spanish-language publication:

No One Writes to the Colonel published 1961 in Spanish (written in 1956-1957), In Evil Hour 1962, One Hundred Years of Solitude 1967, The Story of a Shipwrecked Sailor 1970, The Autumn of the Patriarch 1975, Chronicle of a Death Foretold 1981, The Fragrance of Guava 1982 with Plinio Apuleyo Mendoza, The Solitude of Latin America 1982, Love in the Time of Cholera 1985, Clandestine in Chile 1986, The General in His Labyrinth 1989, Strange Pilgrims 1993, Of Love and Other Demons 1994, News of a Kidnapping 1996, Memories of My Melancholy Whores 2004.

${ }^{2}$ Bogotazo refers to the massive riots that started with the assassination of Colombia of Liberal leader and presidential candidate Jorge Eliecer Gaitan in Bogota in 1948 during the government of President Mariano Ospina Perez. The 10 hours riot left a death toll of 3,000 to 5,000 people and thousands injured, and left much of downtown Bogota destroyed. The aftershock of Gaitan's murder continued extending through the countryside and triggered a period in the history of Colombia known as La Violencia (The Violence) that lasted until approximately 1958, and laid the foundation for the civil conflict that continues to these days. 